\title{
Analysis of Environmental Risk Factors and Treatment Efforts Malaria Import Patients in Puskesmas in the Work Area of District Health Center of Segeri, Pangkep Regency 2019
}

\author{
Mugfira Mayangsari Putri ${ }^{1}$, Hasanuddin Ishak ${ }^{2}$, Indar ${ }^{3}$, Anwar Mallongi ${ }^{2}$ \\ ${ }^{1}$ Scholar Researcher of Department of Environmental Health, Faculty of Public Health, Hasanuddin University, \\ ${ }^{2}$ Professor of Department of Environmental Health, Faculty of Public Health, Hasanuddin Universit, ${ }^{3}$ Professor of \\ Health Policy Administration, Faculty of Public Health, Hasanuddin University
}

\begin{abstract}
Malaria is transmitted by female Anopheles mosquito bites. Plasmodium carried by mosquito bites will live and multiply in human red blood cells. This study aims to determine the relationship between environmental risk factors and treatment efforts in patients with Imported Malaria in the work area of the District Health Center of Segeri, Pangkep Regency.

This type of research is observational analytic using a case-control design. The sampling technique for case groups is exhaustive sampling. Control group sampling is adjusted based on the number of sample cases as many as 40 cases with a ratio of 1:1 with a total of 80 respondents. Data analysis was performed univariate, bivariate (Chi-square yielded Odds Ratio (OR), and multivariate (logistic regression).

The results of the bivariate analysis showed an association between malaria sufferers in the migration area $(\mathrm{p}=0.017 ; \mathrm{OR}=3.273)$, nighttime habits $(\mathrm{p}=0.025 ; \mathrm{OR}=2,786)$, wearing closed clothes $(\mathrm{p}=0.044 ; \mathrm{OR}=2.500)$, using mosquito nets at night $(\mathrm{p}=0.043 ; \mathrm{OR}=2.538)$, history of suffering from malaria $(\mathrm{p}=0.029 ; \mathrm{OR}=9.750)$, knowledge about the causes of malaria $(\mathrm{p}=0.012$; OR=6.333), knowledge about malaria transmission $(\mathrm{p}=0.027 ; \mathrm{OR}=2.143)$, knowledge about the clinical symptoms of malara $(\mathrm{p}=0.029 ; \mathrm{OR}=9.750)$, knowledge about the type of malaria treatment $(\mathrm{p}=0.025 ; \mathrm{OR}=3.857)$, knowledge about malaria prevention $(\mathrm{p}=0.025$; $\mathrm{OR}=3.857)$, and have attended/heard of malaria counseling $(\mathrm{p}=0.027$; $\mathrm{OR}=2.143)$ with imported malaria. Multivariate analysis showed that the most dominant factor associated with imported malaria was the use of mosquito nets in the migration area (Wald $=6.604$; Exp. $(B)=5.239 ; 95 \%$ CI 1.481-18.526).

The solution provided is the need to increase awareness of protecting the environment specifically with the use of mosquito nets in the migration area, increasing knowledge of malaria and prevention by counseling and awareness to take chemoprophylaxis for people who want to migrate.
\end{abstract}

Keywords: Environment, Medicine, Import Malaria, Pangkep

\section{Introduction}

Risk factors for malaria transmission, such as environmental factors, the presence of vectors and uncontrolled Plasmodium can cause malaria to reemerge. Plasmodium sp can hide in the human body, but does not cause symptoms (carrier). If there are environmental changes that support the development of Anopheles sp, contact will begin and malaria can reappear ${ }^{1}$. Other influential factors are the existence of mosquito breeding sites around the house, the environment inside and outside the house, the habit of going out at night, and the level of knowledge about malaria treatment ${ }^{2}$. That is why eradication of malaria through appropriate treatment needs to be done.

Eradication of malaria through treatment can break the chain of transmission if done properly and correctly. In addition, related to the time of seeking treatment, a delay in treatment can cause death in adults up to $25 \%$ 
in 2 weeks after the occurrence of primary infection. In addition, the impact of malaria infection and treatment failure can result in anemia, fetal death, prematurity, low birth weight, and high economic loss. Therefore, treatment and treatment need to be done quickly and precisely to reduce morbidity, prevent severe and complications, prevent transmission, and minimize the impact of the disease on public health ${ }^{2}$

Data from the Pangkep District Health Office in 2016, the clinical Malaria number was 202 cases with 53 positive cases (API $0.16 \%$ ). In 2017 the clinical Malaria number was 145 cases with 65 positive cases (API $0.21 \%$ ) and in 2018 the number of clinical malaria cases was 52 with 26 positive cases (API $0.11 \%$ ). One of the Subdistricts in Pangkep Regency that has a high API number of 3 consecutive years is the Segeri Subdistrict with a high import Malaria case found in two villages (Segeri and Baring) each year and is fluctuating, namely in 2016 the API values are respectively 0, $07 \%$ and $0.56 \%$, increased in 2017 to $0.59 \%$ and $0.70 \%$, and again declined in 2018 with API values $0.39 \%$ and $0.42 \%{ }^{3}$.

Even though malaria positive cases over the past three years are still categorized as Low Case Incidence with API value $<1 / 1000$ population, but it remains a big concern in efforts to eliminate Malaria because it cannot be categorized as a Malaria-free area and almost all sufferers are imported Malaria sufferers who cases continue to be found every year.

\section{Materials and Method}

\section{Design of Research and Location}

Research using quantitative methods, analytic observational design with a case control approach with matching age and gender categories in the control group. Environmental risk factors and treatment efforts in this study are independent variables while imported malaria sufferers are the dependent variable.

\section{Population and sample}

The population of this study were all respondents whose blood preparations were found by Plasmodium based on the results of microscopic examination / Rapid Diagnostic Test (RDT) in the work area of Segeri Puskesmas and Baring Puskesmas that migrated / migrated in the last 3 years 2017-2019. The sample in this study consisted of 40 respondents in the case group namely respondents who were migrants and positive malaria and the control group were respondents who were migrants and negative malaria, with a comparison of case: control samples was 1: 1 , so the number of samples was 80 respondents.

\section{Data analysis}

The data analysis technique of this study used univariate analysis, bivariate with Chi Square test resulted in Odds Ratio (OR), and multivariate analysis with logistic regression with Statistical Package for the Social Sciences (SPSS) 21.0 for windows program.

\section{Results}

\section{Environmental risk}

Table 1. The results of risk factor analysis of the habit of going out at night show that the p-value of the study was $0.025(0.025<0.05)$ with Odds ratio (OR) $=2.786$ with lower limit $(\mathrm{LL})=1.125$ and upper limit $(\mathrm{UL})=6,899$ indicates a positive relationship between the habit of going out at night in the migration area with imported malaria.

Table 1. Bivariate Analysis of Environmental Variables on Patients with Imported Malaria in the Work Area of the Segeri District Health Center in Pangkep Regency in 2019

\begin{tabular}{|c|c|c|c|c|c|c|c|c|c|c|}
\hline \multirow{2}{*}{ Variable } & \multicolumn{2}{|c|}{ Case } & \multicolumn{2}{|c|}{ Control } & \multicolumn{2}{|c|}{ Total } & \multirow{2}{*}{ p- Value } & \multirow{2}{*}{ OR } & \multicolumn{2}{|c|}{$95 \%$ CI } \\
\hline & $n$ & $\%$ & $\mathrm{n}$ & $\%$ & $\mathbf{N}$ & $\%$ & & & Lower & Upper \\
\hline \multicolumn{11}{|c|}{ Going out at night } \\
\hline Yes & 26 & 65.0 & 16 & 40.0 & 26 & 65.0 & \multirow{2}{*}{0,025} & \multirow{2}{*}{2.786} & \multirow{2}{*}{1.125} & \multirow{2}{*}{6.899} \\
\hline No & 14 & 40.0 & 24 & 60.0 & 14 & 40.0 & & & & \\
\hline
\end{tabular}


Cont... Table 1. Bivariate Analysis of Environmental Variables on Patients with Imported Malaria in the Work Area of the Segeri District Health Center in Pangkep Regency in 2019

\begin{tabular}{|c|c|c|c|c|c|c|c|c|c|c|}
\hline Wea & & & & & & & & & & \\
\hline Yes & 25 & 62.5 & 16 & 40.0 & 25 & 62.5 & \multirow{2}{*}{0,044} & \multirow{2}{*}{2.500} & \multirow{2}{*}{1.016} & \multirow{2}{*}{6.149} \\
\hline No & 15 & 37.5 & 24 & 60.0 & 15 & 37.5 & & & & \\
\hline \multicolumn{11}{|c|}{ Wear Mosquito Nets at Night } \\
\hline Yes & 27 & 67.5 & 18 & 45.0 & 27 & 67.5 & 0,043 & 2.538 & 1.023 & 6.298 \\
\hline No & 13 & 32.5 & 22 & 55.0 & 13 & 32.5 & & & & \\
\hline
\end{tabular}

Table 1. The results of risk factor analysis using mosquito nets at night show that the p-value of the study was $0.043(0.044<0.05)$ with $\mathrm{OR}=2.538$ with lower limit $(\mathrm{LL})=1.023$ and upper limit $(\mathrm{UL})=6.298$ indicating a relationship positive between using mosquito nets at night in the migration area with imported malaria. Respondents who do not use mosquito nets at night have a risk of contracting malaria in the migration area of 2,538 times greater.

\section{Treatment effort}

Table 2. The results of the analysis of risk factors for history of malaria showed that the p-value of the study was $0.029(0.029<0.05)$ with $\mathrm{OR}=9,750$ with lower limit $(\mathrm{LL})=1,158$ and upper limit $(\mathrm{UL})=82,108$ showed a positive relationship between history of having suffered from malaria before migrating with imported malaria. Respondents who have a history of malaria before migrating are at risk of getting malaria in the migration area 9,750 times greater.

Table 2. Bivariate Analysis of Variable Treatment Efforts to Patients with Imported Malaria in the Work Area of Segeri District Health Center in Pangkep Regency in 2019

\begin{tabular}{|c|c|c|c|c|c|c|c|c|c|c|}
\hline \multirow{2}{*}{ Variable } & \multicolumn{2}{|c|}{ Case } & \multicolumn{2}{|c|}{ Control } & \multicolumn{2}{|c|}{ Total } & \multirow{2}{*}{$\begin{array}{l}\text { p- } \\
\text { Value }\end{array}$} & \multirow{2}{*}{ OR } & \multicolumn{2}{|c|}{$95 \% \mathrm{CI}$} \\
\hline & $\mathbf{n}$ & $\%$ & $\mathbf{n}$ & $\%$ & $\mathbf{n}$ & $\%$ & & & Lower & Upper \\
\hline \multicolumn{11}{|c|}{$\begin{array}{l}\text { Take Anti-Malaria } \\
\text { Medication }\end{array}$} \\
\hline Yes & 0 & 0 & 0 & 0 & 0 & 0 & \multirow{2}{*}{-} & \multirow{2}{*}{ - } & \multirow{2}{*}{-} & \multirow{2}{*}{-} \\
\hline No & 40 & 100 & 40 & 100.0 & 40 & 100 & & & & \\
\hline \multicolumn{11}{|c|}{ History of malaria } \\
\hline Yes & 8 & 20 & 1 & 2.5 & 8 & 20 & \multirow{2}{*}{0,029} & \multirow{2}{*}{9.750} & \multirow{2}{*}{1.158} & \multirow{2}{*}{82.108} \\
\hline No & 32 & 80 & 39 & 97.5 & 32 & 80 & & & & \\
\hline \multicolumn{11}{|c|}{$\begin{array}{l}\text { Types of Malaria } \\
\text { Treatment }\end{array}$} \\
\hline Yes & 12 & 30 & 4 & 10 & 12 & 30 & 0,025 & 3.857 & 1.122 & 13.258 \\
\hline No & 28 & 70 & 35 & 90 & 28 & 70 & & & & \\
\hline
\end{tabular}


Cont. Table 2. Bivariate Analysis of Variable Treatment Efforts to Patients with Imported Malaria in the Work Area of Segeri District Health Center in Pangkep Regency in 2019

\begin{tabular}{|l|l|l|l|l|l|l|l|l|l|l|}
\hline $\begin{array}{l}\text { Prevention of } \\
\text { Malaria }\end{array}$ & & & & & & & & & & \\
\hline Yes & 12 & 30 & 4 & 10 & 12 & 30 & 0,025 & 3.857 & 1.122 & 13.258 \\
\hline No & 28 & 70 & 36 & 90 & 28 & 70 & & & & \\
\hline $\begin{array}{l}\text { Follow/ Hear } \\
\text { Malaria Counseling }\end{array}$ & & & & & & & & & & \\
\hline Yes & 0 & 0.0 & 5 & 12.5 & 0 & 0 & 0,027 & 2.143 & 1.682 & 2.729 \\
\hline No & 40 & 100 & 35 & 87.5 & 40 & 100 & & & & \\
\hline
\end{tabular}

Table 2. The results of the analysis of risk factors following counseling on malaria indicate that the p-value of the study was $0.027(0.027<0.05)$ with $\mathrm{OR}=2.143$ with a lower limit value $(\mathrm{LL})=1,682$ and upper limit $(\mathrm{UL})=2,729$ indicating a positive relationship between having attended / heard of malaria counseling with imported malaria. Respondents who did not attend counseling had a 2,729 times greater risk of malaria.

\section{Multivariate analysis}

Table 3. Results of Logistic Regression Analysis of Risk Factor Variables with Malaria Patients in the Work Area of the Segeri District Health Center in Pangkep Regency in 2019

\begin{tabular}{|l|l|l|l|l|l|l|}
\hline No. & Covariate & B & S.E & Wald & p-value & Exp.(B) \\
\hline 1. & The Habit of Going Out at Night & 0.657 & 1.577 & 0.174 & 0.677 & 1.930 \\
\hline 2. & Wearing Closed Clothes & 0.129 & 1.558 & 0.007 & 0.934 & 1.138 \\
\hline 3. & Wearing a Mosquito Net & 1.656 & 0.644 & 6.604 & 0.060 & 5.239 \\
\hline 4. & History of Malaria & 0.749 & 1.838 & 0.166 & 0.684 & 0.473 \\
\hline 5. & $\begin{array}{l}\text { Knowledge of the Types of Malaria } \\
\text { Treatment }\end{array}$ & 1.108 & 2.093 & 0.280 & 0.597 & 3.027 \\
\hline 6. & Knowledge of Malaria Prevention & 1.380 & 1.649 & 0.701 & 0.403 & 3.976 \\
\hline 7. & Follow / Hear Malaria Counseling & -10.421 & 8035 & 0.000 & 0.999 \\
\hline
\end{tabular}

\section{Discussion}

Respondents in this study were $100 \%$ using ordinary mosquito nets, not insecticide-treated nets, even though they were living in malaria endemic areas. One of the efforts to prevent malaria transmission is personal protection by reducing contact between humans and vectors, namely interventions to use insecticidetreated mosquito nets ${ }^{4}$. The use of insecticide-treated 
mosquito nets in some rural areas has been acceptable to the community, although not all family members use mosquito nets to bedtime continuously ${ }^{5}$

Meanwhile, the p-value in this study for the habit of wearing closed clothing at night was 0.044 , which means that there is a relationship between the habit of wearing closed clothing with imported malaria sufferers in the migration area. The use of long-sleeved clothes and long pants when going out outside the house at night is still not a habit for respondents. Not wearing long sleeves and long pants when doing activities outside the house at night is a risk factor for malaria in the Kapoposang Pangkep island area ${ }^{6}$. Respondents said that they were accustomed to not wearing long sleeves and long pants when leaving the house at night, except for certain activities such as recitation and going to the mosque ${ }^{7,8}$.

Consumption of anti-malaria drugs or commonly known as chemoprophylaxis in this study $100 \%$ or 80 total respondents did not take anti-malaria drugs before migrating. The main reason for respondents is not knowing about this drug and not having time to take it. So it cannot be tested in a bivariate analysis because all respondents' answers are homogeneous. Even though the respondent's response was homogeneous, not taking this anti-malaria drug is a risk factor for imported malaria that deserves attention.

The history of suffering from malaria in this study was interpreted as respondents who had experienced malaria before migrating / to overseas areas. The value of $p=0.012$ and OR of 9,750 which means a history of suffering from malaria before migrating is one of the factors of the occurrence of imported malaria. Research by Pratamawati et al., ${ }^{9}$ in the area of Magelang Regency which is a combination of import cases and indigenous cases. The case description is known to be mostly male with age $<45$ years, as well as most occupations as laborers and all case respondents had experienced malaria before.

Respondents' knowledge in this research is knowledge related to the type of medication and how to prevent malaria. The results of the bivariate analysis showed that the value of each research p-value was 0.025 with a $p$ value $<0.05$ meaning Ho was rejected, meaning that there was a relationship between knowledge of malaria against imported malaria sufferers. The majority of respondents to the study conducted by Spjeldnæs et al. ${ }^{10} 82.1 \%$ of respondents correctly identified mosquitoes as an infectious agent, mosquito nets as a prevention tool $(85.2 \%)$ and hospitals according to the needs of care facilities (96.4\%). On the other hand, there are conflicting opinions about general malaria symptoms, more than half $(58.2 \%)$ cite fever as a symptom of malaria, and only one third (32.7\%) cite other common symptoms such as headaches, vomiting and body aches. Overall only $17.3 \%$ of the total respondents were able to answer correctly.

People who get health education will be wellinformed compared to people who have not been provided health education ${ }^{11}$. According to (Notoatmodjo, 2012) knowledge consists of various levels, namely know, understand, application, analysis, synthesis and evaluation. Referring to the theory, it can be concluded that the majority of respondents to this study were only at the level of tofu, against malaria. Knowledge is usually influenced by the level of education ${ }^{12}$.

Based on the results of bivariate analysis shows that the research p-value of $0.027(0.027<0.05)$ means that Ho is rejected, meaning that there is a relationship between having attended / heard of malaria counseling by Malaria interpreters at the local health center against imported malaria patients. Then the Odds ratio test value obtained OR value $=2,143$ shows that respondents who did not follow / hear counseling about malaria had a risk of getting malaria 2,729 times greater. Respondents in this study $87.5 \%$ or the majority never attended or listened to malaria counseling, either at the migration / overseas location or in their place of residence.

Research also conducted by Arisanti et al., ${ }^{13}$ obtained the results of counseling programs on malaria carried out by health workers that have not touched the community, so that in general the public expects counseling to be carried out by health workers that goes on continuously. Based on the results of the analysis of the research questionnaire by Trisnadewi et al., ${ }^{14}$ most respondents did not get information related to the importance of malaria prevention efforts. The low level of knowledge owned by respondents is because respondents have never attended counseling, so the lack of information received by respondents related to the above. The statement is consistent with the theory that the purpose of counseling 
is to change unhealthy behaviors into healthy ones. New behaviors that are formed are usually limited to aspects of knowledge, while changes in attitudes and behaviors are indirect effects of counseling ${ }^{15-16}$.

\section{Conclusions}

Based on the results of research and discussion, it can be concluded that the environmental risk variables and treatment efforts affect imported malaria patients. The habit of using mosquito nets is the most dominant factor against imported malaria. The solution provided is the need to increase awareness of protecting the environment specifically with the use of mosquito nets in the migration area and awareness of taking chemoprophylaxis for people who want to migrate.

\section{Source of Funding : Self}

Ethical Clearance: obtained from public health faculty ethical committee

\section{Conflict of Interest : None}

\section{References}

1. Hakim, L., Wahono, T., Ruliansyah, A. \& Kusnandar, A. J. Potensi Kemunculan Kembali Malaria di Kabupaten Pangandaran Aspirator, 2018; 10(1):37-48.

2. Dinkes Pangkep. Cakupan Penyakit Malaria Tahun 2016-2018. Pangkep, Sulawesi Selatan: Dinas Kesehatan Kabupaten Pangkajene dan Kepulauan. 2019

3. Lai, S. etal., Changing Epidemiology and Challenges of Malaria in China Towards Elimination. malaria Journal BMC, 2019; 18(2017):1-11.

4. Jacob, V. \& Nuuyoma, V. Knowledge, Attitudes and Practices of the University Students on Malaria Prevention in Kavango East, Namibia Global Journal of Health Science, 2019; 11(2):102-109.

5. Indriyati, L., Juhairiyah \& Yuana, W. T. The Ownership, Utilizing, and Maintance of Long Lasting Insecticidennets by The Household in Malaria Endemic Areas Kotabaru District, South Kalimantan. Journal of Health Epidemiology and Communicable Diseases (JHECDs),2015; 1(1):813.

6. Arsin, A. \& Situmorang, A. S. Environmental Effect of Settlement Againts Malaria Incidence on The Island of Kapoposang Pangkajene Island
District. Medwell Journal, 2015; 10(6):1528-1534.

7. Arsin, A. A. Malaria di Indonesia : Tinjauan Aspek Epidemiologi, Makassar, Masagena Press. 2012.

8. Alami, R. \& Adriyani, R. Tindakan Pencegahan Malaria di Desa Sudorogo Kecamatan Kaligesing Kabupaten Purworejo. Jurnal Promkes, 2016; 4(2):199-211.

9. Pratamawati, D. A., Susanti, L., Nugroho, S. S., Mujiyono \& Martiningsih, I. Gambaran Daerah Reseptif Malaria di Kecamatan Salaman Kabupaten Magelang Jawa Tengah. SPIRAKEL, 2018; 10(2):63-77.

10. Spjeldnæs, A. O., Kitua, A. Y. \& Blomberg, B. Education and Knowledge Helps Combating Malaria, but not Degedege: A Cross-Sectional Study in Rufiji, Tanzania. Malaria Journal BioMed Central, 2014; 13(200):1-10.

11. Kusumawardani, E.. Pengaruh Penyuluhan Kesehatan terhadap Tingkat Pengetahuan, Sikap dan Praktik Ibu dalam Pencegahan Demam Berdarah Dengue terhadap Anak. Artikel Jurnal Media Medika Muda. 2015; Semarang: Universitas Diponogoro.

12. Notoatmodjo, S. Promosi Kesehatan dan Perilaku Kesehatan, Jakarta, Rineka Cipta. 2012

13. Arisanti, M., Sitorus, H. \& Wurisastuti, T. Pengendalian Malaria di Desa Tebat Gabus oleh Penyelenggara Kesehatan Melalui Peningkatan Pengetahuan, Sikap dan Perilaku Masyarakat. SPIRAKEL, 2016; 8(1):38-46.

14. Trisnadewi, E., Sari, I. K. \& Marlinda, R.. Correlation of Knowledge and Attitude With The Casemof Malaria Diseasein The Work Area of Primary Health Care of Sioban Mentawai Island District. Jurnal Kesehatan Saintika Meditory, 2016; 2(1):108-114.

15. Birawida, A.B., Selomo, M., Mallongi, A. Potential hazards from hygiene, sanitation and bacterium of refill drinking water at Barrang Lompo island (water and food safety perspective) IOP Conference Series: Earth and Environmental Science 2018; Volume 157, Issue 1, Article number 012034

16. Mallongi, A., Parkpian, P., Pataranawat, P., Chinwetkitvanich, S. Mercury distribution and its potential environmental and health risks in aquatic habitat at artisanal buladu gold mine in Gorontalo Province, Indonesia. Pakistan Journal of Nutrition, 2015; Volume 14, Issue 12, Pages 1010-1025 